\title{
Profil Hematologi Ikan Gabus (Channa striata Bloch, 1793)
}

\author{
Esti Lestari $^{1}$,Tri Rima Setyawati ${ }^{1}$, Ari Hepi Yanti ${ }^{1}$ \\ ${ }^{1}$ Program Studi Biologi, Fakultas MIPA, Universitas Tanjungpura,Jl. Prof. Dr.H. Hadari Nawawi, Pontianak, \\ Email korespondensi :1_esti@yahoo.com
}

\begin{abstract}
The hematology profile that include hematocrite value, erythrocyte count, leucocyte count, differential leucocyte can used to determined the health state and diagnosis of fish diseases. The purpose of this research is to study the hematology profiles of gabus (Channa striata). This research was conducted on August to October 2016. Gabus with body length about $25-35 \mathrm{~cm}$ and the blood samples were collected from vena caudalis (caudal vein) to evaluate hematocrite value, erythrocyte count, leucocyte count, eythrocyte and leucocyte diameter and differential leucocyte. The result of the research showed that hematocrite values $23,25-24,83 \%$, erythrocyte counts $2,34-2,51 \times 10^{6} \mathrm{cell} / \mathrm{mm}^{3}$, erythrocyte diameter 7,69-8,16 $\mu \mathrm{m}$, leucocyte counts $1,53-1,65 \times 10^{5} \mathrm{cell} / \mathrm{mm}^{3}$, leucocyte diameter 5,73-6,53 $\mu \mathrm{m}$, monocytes 5,73-6,53\%, limphocytes 76,13$78,20 \%$ and neutrophils $16,07-17,40 \%$.
\end{abstract}

Kata Kunci: Channa striata, hematology, erythrocyte, leucocyte, hematocrite

\section{PENDAHULUAN}

Konsumsi ikan air tawar di masyarakat sudah mulai mengalami peningkatan sehingga usaha budidaya ikan juga berkembang. Salah satu jenis ikan air tawar yang biasa dikonsumsi adalah ikan gabus (Channa striata, Bloch). Ikan ini memiliki kandungan albumin yang tinggi sehingga dapat digunakan untuk mengobati penyakit tertentu (Santoso et al., 2009).

Usaha budidaya ikan air tawar mengalami kendala akibat kondisi lingkungan yang semakin menurun. Kualitas air dan lingkungan yang rusak akan memicu berkembangnya virus dan penyakit pada ikan (Andayani et al., 2014). Menurut Onyia et al. (2013), kehidupan ikan sangat berhubungan dengan habitatnya.Perubahan lingkungan secara fisik atau kimia akan mempengaruhi komponen darah ikan.Jika ikan terpapar pada senyawa kimia tertentu akan meningkatkan atau menurunkan level hematologisnya. Anemia merupakan salah satu gangguan yang terjadi pada jaringan darah ikan. Gangguan ini terjadi akibat ikan terpapar oleh polutan kimia atau logam-logam berat sehingga terjadi disfungsi pada organ osmoregulator (Heath, 1995).

Darah merupakan salah satu parameter yang dapat digunakan untuk melihat kelainan yang terjadi pada ikan, baik yang terjadi karena penyakit ataupun karena keadaan lingkungan. Ikan yang terserang penyakit akan mengalami perubahan pada nilai hematokrit, kadar hemoglobin, jumlah sel darah merah dan jumlah sel darah putih. Pemeriksaan darah dapat digunakan sebagai indikator tingkat keparahan suatu penyakit. Studi hematologis merupakan kriteria penting untuk diagnosis dan penentuan kesehatan ikan (Hidayat et al.,2014).

Kajian tentang profil hematologi pada beberapa spesies ikan telah banyak dilakukan, contohnya hematologi ikan lele dumbo (Andayani et al., 2014), hematologi ikan kerapu tikus (Samsisko, 2013), dan hematologi ikan nila (Hartika et al., 2014). Kajian tersebut dapat digunakan untuk membandingkan status kesehatan ikan yang sehat dan sakit. Tujuan dari penelitian ini adalah untuk mengetahui profil hematologi ikan gabus yang meliputi nilai hematokrit, jumlah eritrosit, jumlah leukosit dan diferensial leukosit.

\section{BAHAN DAN METODE}

\section{Waktu dan tempat}

Penelitian dilakukan selama 3 bulan mulai dari bulan Agustus hingga Oktober 2016. Penelitian ini dilaksanakan di Laboratorium Zoologi Fakultas Matematika dan Ilmu Pengetahuan Alam Universitas Tanjungpura Pontianak.

\section{Alat dan Bahan Penelitian}

Alat-alat yang diperlukan adalah spuit, gelas obyek, gelas penutup, hemositometer, mikroskop Olympus CHX21, cawan petri, pipet tetes, hand 
counter, mesin sentrifuse hematokrit SH120II, tabung mikrokapiler, penutup tabung mikrokapiler (lilin), penggaris dan vacuum tube. Bahan yang digunakan adalah ikan gabus berjumlah 30 ekor (15 jantan dan 15 betina) dengan ukuran sekitar 25-35 $\mathrm{cm}$, anti koagulan (EDTA), larutan hayem, larutan turk, pewarna giemsa, metanol, akuades, alkohol $70 \%$, kertas label dan kertas tisu.

\section{Prosedur Kerja \\ Pengambilan Sampel Darah}

Jarum spuit ditusukkan pada garis tengah tubuh di belakang sirip anal. Jarum dimasukkan ke dalam musculus sampai mencapai tulang belakang. Kemudian spuit ditarik perlahan-lahan sampai darah masuk ke dalam spuit. Setelah itu darah dimasukkan ke dalam vacuum tube yang telah diberi anti koagulan dan kertas label.

\section{Perhitungan Nilai Hematokrit dengan Metode Mikrohematokrit}

Tabung mikrokapiler diisi dengan darah ikan hingga mencapai $3 / 4$ bagian tabung. Setelah itu ujung tabung ditutup dengan penutup tabung. Tabung kemudian dimasukkan ke dalam mesin sentrifuse hematokrit dengan kecepatan 5000 rpm selama 5 menit. Setelah 5 menit, mesin dimatikan dan tabung dikeluarkan lalu nilai hematokrit ditentukan dengan pengukuran menggunakan penggaris (Samsisko, 2013).

\section{Perhitungan Jumlah Eritrosit}

Darah dihisap dengan pipet eritrosit sampai batas 0,5. Kemudian darah dicampur dengan larutan Hayem sampai batas 101 yang tertera pada pipet. Isi pipet dikocok dengan membuat gerakan angka 8 agar tercampur. Cairan kemudian dimasukkan ke kamar hitung kemudian dilakukan penghitungan di bawah mikroskop. Kamar hitung dengan bidang bergaris diletakkan di bawah obyektif dan fokus mikroskop diarahkan pada garis-garis bagi tersebut dan eritrosit akan terlihat. Semua eritrosit dihitung yang terdapat dalam 5 bidang yang tersusun dari 16 bidang kecil. Eritrosit dihitung dari sudut kiri atas, terus ke kanan, kemudian turun ke bawah dan dari kanan ke kiri dan seterusnya (Pal \& Pal, 2006). Rumus perhitungan jumlah eritosit:

$$
\mathrm{N}=\mathrm{n} \times 10^{4}
$$

$\begin{array}{ll}\text { Keterangan } & : \\ \mathrm{n} & : \text { jumlah sel darah merah yang } \\ & \text { terdapat dalam } 80 \text { kotak kecil } \\ \mathrm{N} & : \begin{array}{l}\text { jumlah sel darah merah dalam } 1 \\ \text { mm }{ }^{3} \text { darah }\end{array}\end{array}$

\section{Perhitungan Jumlah Leukosit}

Darah dihisap dengan pipet eritrosit sampai batas 0,5. Kemudian darah dicampur dengan larutan Turk sampai batas 11 yang tertera pada pipet. Isi pipet dikocok dengan membuat gerakan angka 8 agar tercampur. Cairan kemudian dimasukkan ke kamar hitung kemudian dilakukan penghitungan di bawah mikroskop. Kamar hitung dengan bidang bergaris diletakkan di bawah obyektif dan fokus mikroskop diarahkan pada garis-garis bagi tersebut dan leukosit akan terlihat. Semua leukosit yang terdapat dalam keempat bidang besar dihitung pada sudut-sudut seluruh permukaan yang terbagi. Leukosit dihitung dari sudut kiri atas, terus ke kanan, kemudian turun ke bawah dan dari kanan ke kiri dan seterusnya (Pal \& Pal, 2006).

Rumus perhitungan jumlah leukosit:

$$
\mathrm{N}=\mathrm{nx} 50
$$

$$
\begin{array}{ll}
\begin{array}{l}
\text { Keterangan } \\
\mathrm{n}
\end{array} & : \\
\mathrm{N} & \begin{array}{l}
\text { jumlah sel darah putih yang terdapat } \\
\text { dalam } 64 \text { kotak }
\end{array} \\
& \begin{array}{l}
\text { jumlah sel darah putih dalam } 1 \mathrm{~mm}^{3} \\
\text { darah }
\end{array}
\end{array}
$$

\section{Sediaan Apus Darah (Pengamatan Diferensial Leukosit)}

Sebanyak dua buah gelas obyek digunakan untuk pembuatan sediaan apus darah, yaitu gelas obyek A dan gelas obyek B. Darah diteteskan pada gelas obyek A, kemudian gelas obyek B ditempelkan pada tetes darah di gelas obyek A dengan sudut $45^{\circ}$. Gelas obyek B ditarik ke sisi kanan lalu didorong ke sisi kiri dengan cepat dan konstan. Setelah didapatkan film darah yang tipis, kemudian dikering anginkan. Setelah itu, preparat apusan dimasukkan kedalam metanol selama 5 menit, jika telah selesai preparat tersebut dimasukkan kedalam pewarna giemsa selama 20 menit. Kemudian dicuci dengan air mengalir selama 5 menit dan dikeringkan. Jika preparat telah kering, preparat diamati dengan menggunakan mikroskop (Klontz, 2009).

Perhitungan diferensial leukosit dilakukan dengan cara menemukan sel darah putih minimal berjumlah 100 sel untuk menentukan persentase jenis leukosit (Pal \& Pal, 2006).

\section{Analisis Data}

Perbedaan profil hematologi (nilai hemetokrit, jumlah eritrosit, jumlah leukosit dan diferensial leukosit) pada ikan gabus (C. striata) dianalisis dengan menggunakan uji t pada taraf nyata 0,05 . 


\section{HASIL DAN PEMBAHASAN}

Hasil

Hasil penelitian profil hematologis ikan gabus $(C$. striata) dapat dilihat pada Tabel1. Ikan gabus jantan rata-rata lebih panjang dan lebih beratdibandingkan ikan gabus betina.

Tabel 1. Profil Hematologi Ikan Gabus Jantan dan Betina

\begin{tabular}{lccc}
\hline \multirow{2}{*}{ Parameter } & \multicolumn{2}{c}{ Gabus } & \multirow{2}{*}{ Prob. } \\
\cline { 2 - 3 } & Jantan & Betina & \\
\hline Panjang (cm) & 29,33 & 29,00 & - \\
Berat (g) & 197,00 & 193,33 & - \\
Hematokrit (\%) & 24,40 & 23,25 & 0,258 \\
Eritrosit $\left(10^{4} \mathrm{sel} / \mathrm{mm}^{3}\right)$ & 250,53 & 233,67 & 0,565 \\
Diameter Eritrosit & 8,16 & 7,69 & - \\
N=50, ${ }^{\lambda}=5 \mathrm{n}+=5$ & & & \\
Leukosit $\left(10^{3} \mathrm{sel} / \mathrm{mm}^{3}\right)$ & 153,51 & 164,67 & 0,061 \\
Diameter Leukosit & 7,82 & 7,24 & - \\
N=50, n ${ }^{\lambda}=5 \mathrm{n}+=5$ & & & \\
Monosit $(\%)$ & 6,53 & 5,73 & 0,377 \\
Limfosit $(\%)$ & 76,13 & 78,20 & 0,448 \\
Neutrofil $(\%)$ & 17,40 & 16,07 & 0,603 \\
Basofil & - & - & - \\
Eosinofil & - & - & - \\
\hline
\end{tabular}

Berdasarkan hasil analisis uji $t_{\alpha .05}$, profil hematologi yang meliputi nilai hematokrit, jumlah eritrosit, jumlah leukosit, persentase monosit, persentae limfosit dan persentase neutrofil pada ikan gabus jantan tidak berbeda nyata dengan profil hematologi ikan gabus betina. Diameter eritrosit dan leukosit pada ikan gabus betina lebih besar dibandingkan pada ikan gabus jantan (Tabel 1).

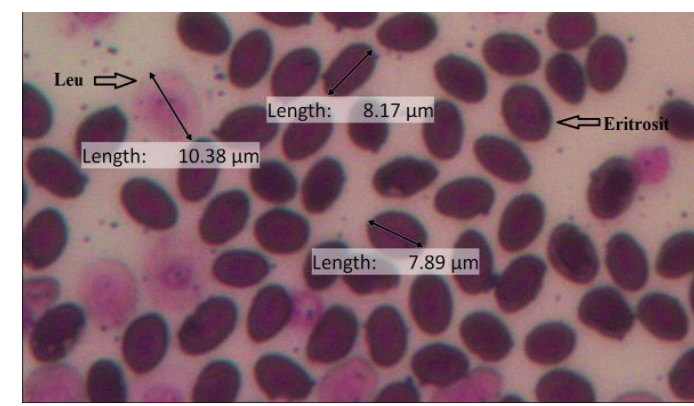

Gambar 1. Eritrosit dan Leukosit pada Ikan Gabus

Terdapat hubungan antara panjang tubuh dan berat tubuh, nilai hematokrit dan jumlah eritrosit, jumlah eritrosit dan jumlah leukosit, panjang tubuh dan jumlah eritrosit serta berat tubuh dan jumlah eritrosit pada ikan gabus (Gambar 2-6).

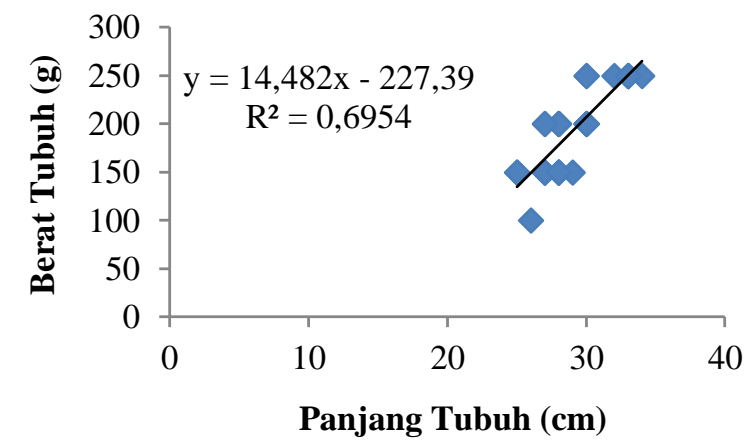

Gambar 2. Hubungan Panjang dan Berat Tubuh Ikan Gabus

Gambar 2. menunjukkan bahwa panjang dan berat tubuh ikan gabus berkorelasi positif, yaitu semakin panjang tubuh ikan gabus maka semakin berat pula tubuhnya.

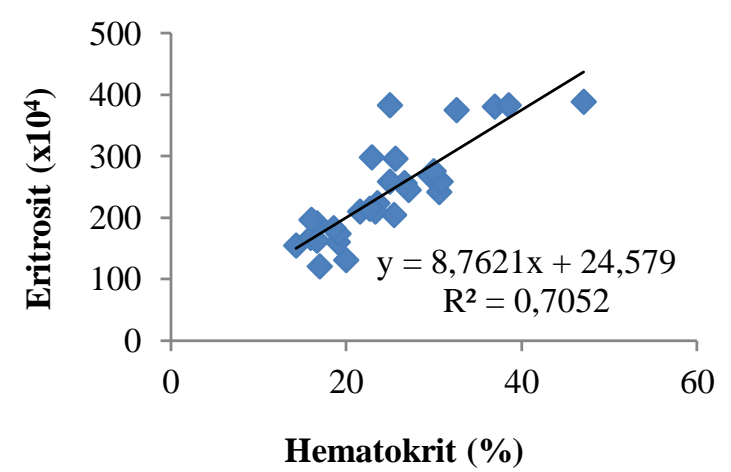

Gambar 3. Hubungan Panjang dan Berat Tubuh Ikan Gabus

Nilai hematokrit dan jumlah eritrositnya pada ikan gabus berkorelasi positif (Gambar 3).

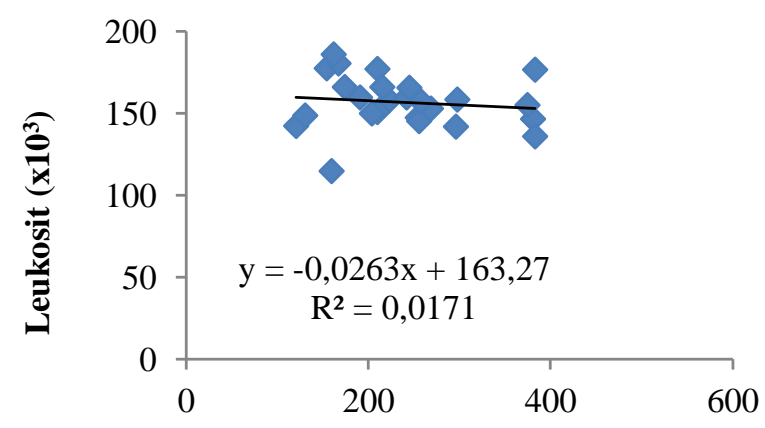

Eritrosit $\left(\mathbf{x 1 0}^{4}\right)$

Gambar 4. Hubungan Jumlah Eritrosit dan Jumlah Leukosit Ikan Gabus

Jumlah eritrosit dan leukosit berkorelasi negatif pada ikan gabus, artinya semakin tinggi jumlah eritrosit maka semakin rendah jumlah leukositnya (Gambar 4). 


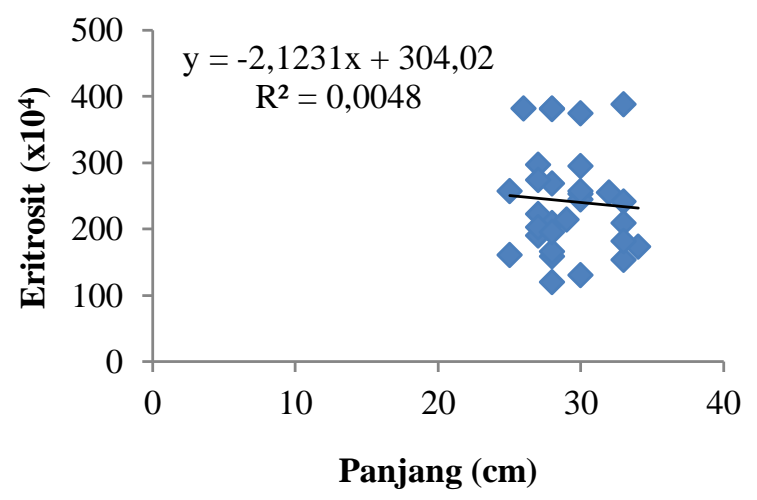

Gambar 5. Hubungan Panjang Tubuh dan Jumlah Eritrosit Ikan gabus

Panjang tubuh dan jumlah eritrosit ikan gabus berkorelasi negatif, yaitu semakin panjang tubuh ikan maka semakin rendah jumlah eritrositnya (Gambar 4).

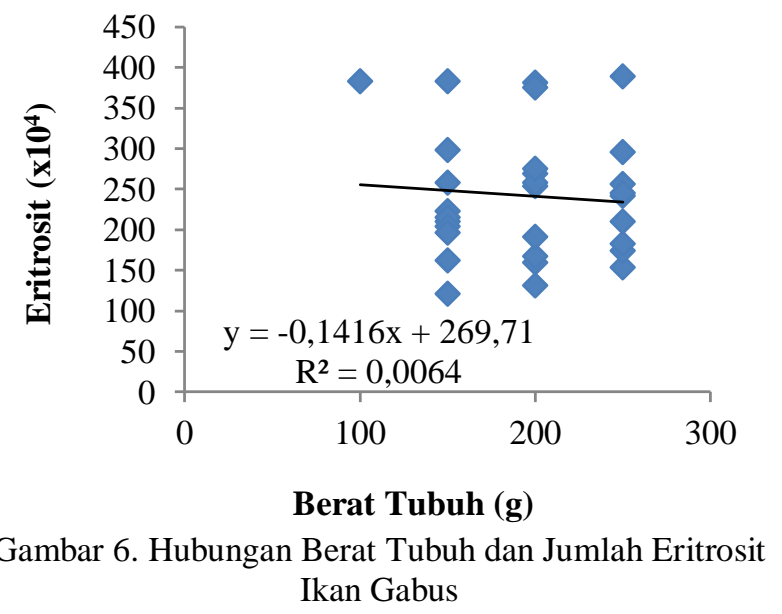

Berat tubuh dan jumlah eritrosit pada ikan gabus berkorelasi negatif, yaitu semakinberat tubuh ikan maka semakin kecil jumlah eritrositnya (Gambar $6)$.

\section{Pembahasan}

Panjang dan berat tubuh ikan merupakan faktor yang mempengaruhi profil hematologi ikan.Ratarata panjang dan berat tubuh ikan gabus jantan lebih besar dibandingkan ikan gabus betina. Panjang dan berat tubuh ikan ikan gabus berkorelasi positif, yaitu semakin panjang tubuh ikan maka semakin berat pula tubuhnya.

Panjang tubuh dan jumlah eritrosit pada ikan gabus berkorelasi negatif, artinya semakin panjang tubuh ikan maka semakin kecil jumlah eritrositnya. Menurut Adebayo et al. (2007), panjang tubuh ikan Parachanna obscura dari famili Channidae berkorelasi negatif dengan jumlah eritrosit. Tidak hanya pada panjang tubuh ikan, berat tubuh juga berkorelasi negatif dengan jumlah eritrosit, yaitu semakin berat tubuh ikan maka semakin kecil jumlah eritrositnya. Panjang dan tubuh ikan yang berkorelasi negatif dengan jumlah eritrosit disebabkan oleh laju metabolisme pada ikan. Semakin besar ukuran tubuh ikan maka semakin kecil laju metabolismenya. Adanya penurunan laju metabolisme juga mengakibatkan penurunan pada jumlah eritrosit ikan (Ikeda, 1970).

Berdasarkan hasil uji t, profil hematologi ikan gabus jantan tidak berbeda nyata dengan ikan betina. Rata-rata tiap parameter hematologi tidak menunjukkan perbedaan yang signifikan, penelitian yang dilakukan Vazquez \& Guerrero (2007) tentang parameter hematologi (nilai hematokrit, jumlah eritrosit, jumlah leukosit dan persentase diferensial leukosit) ikan Cichlasoma dimerus jantan dan betina juga menunjukkan tidak ada perbedaan yang signifikan ketika dianalisis dengan uji t. Walaupun demikian, jenis kelamin merupakan salah satu faktor yang mempengaruhi nilai hematokrit dan jumlah eritrosit pada ikan. Menurut Weiss \& Wardrop (2010), ikan jantan memiliki nilai hematokrit dan jumlah eritrosit yang lebih tinggi dibandingkan dengan ikan betina. Perbedaan rata-rata nilai hematokrit dan jumlah eritrosit yang tidak signifikan kemungkinan dipengaruhi oleh masa pemijahan ikan. Menurut Makmur \& Prasetyo (2006), musim puncak pemijahan ikan gabus berlangsung saat musim penghujan yaitu pada bulan September hingga Desember. Selama masa pemijahan, ikan memerlukan energi yang besar sehingga pada ikan jantan dan betina nilai hematokrit dan jumlah eritrositnya sama-sama meningkat.

Ikan gabus memiliki nilai hematokrit rata-rata $24,40 \%$ pada ikan jantan dan $23,25 \%$ pada ikan betina. Hal ini menunjukkan bahwa nilai hematokrit pada ikan gabus adalah normal. Adebayo et al. (2007) melaporkan bahwa pada ikan $P$. obscura dari famili yang sama dengan ikan gabus (Channidae) memiliki rata-rata nilai hematokrit $26,40 \%$ dan jumlah eritrosit sekitar $2,004 \times 10^{6} \mathrm{sel} / \mathrm{mm}^{3}$. Hematokrit adalah gambaran persentase sel darah merah dalam darah (Hastuti \& Subandiyono, 2010). Menurut Salasia et al. (2001), nilai hematokrit berhubungan langsung dengan jumlah eritrosit ikan, artinya nilai hematokrit akan meningkat jika jumlah eritrosit mengalami peningkatan. Hasil yang diperoleh pada penelitian ini juga menunjukkan bahwa semakin tinggi nilai hematokrit maka semakin tinggi jumlah eritrosit. Nilai hematokrit normal pada ikan Teleostei khususnya ikan air tawar berkisar antara 22\%-60\% (Nabib \& Pasaribu, 1989). 
Campbell (2015) mengungkapkan bahwa kadar hematokrit bervariasi tergantung pada faktor nutrisi, umur, jenis kelamin, ukuran tubuh, dan masa pemijahan. Pengukuran hematokrit dapat dijadikan sebagai salah satu parameter untuk mengetahui kesehatan ikan, contohnya adalah sebagai indikasi stress. Stress pada ikan dapat terjadi akibat beberapa faktor seperti faktor lingkungan, penanganan ketika pengambilan darah (injeksi) maupun karena infeksi patogen (Hardi et al., 2011).

Jumlah eritrosit pada ikan Teleostei berkisar antara $(1,05-3,0) \times 10^{6} \mathrm{sel} / \mathrm{mm}^{3}$ (Robert, 2012). Rata-rata jumlah eritrosit pada ikan gabus $\left(242,1 \times 10^{4}\right.$ $\mathrm{sel} / \mathrm{mm}^{3}$ ) masih dalam kisaran normal baik pada jantan maupun betina.

Rata-rata diameter eritrosit pada ikan gabus jantan $(8,16 \mu \mathrm{m})$ lebih besar dibandingkan ikan betina $(7,69 \mu \mathrm{m})$, akan tetapi keduanya memiliki bentuk sel yang hampir sama yaitu berbentuk oval dengan inti di tengah. Diameter eritrosit ikan gabus dan lebih kecil dibandingkan ikan mas yaitu sekitar 10,32 $\mu \mathrm{m}$ dan pada ikan nila sekitar 9,24 $\mu \mathrm{m}$ (Salasia et al., 2001). Menurut Maciak et al. (2011), perbedaan ukuran sel pada ikan dapat disebabkan oleh beberapa hal, yaitu umur, laju pertumbuhan individu, ketahanan dalam kecepatan berenang dan laju metabolisme. Ikan yang memiliki diameter eritrosit yang kecil, laju metabolismenya lebih tinggi dibandingkan dengan ikan yang diameternya lebih besar. Ikan gabus memiliki laju metabolisme yang besar dibandingkan ikan mas dan ikan nila yang memiliki diameter eritrosit yang lebih besar.

Leukosit merupakan komponen sel darah yang berperan sebagai sistem pertahanan tubuh ikan (Robert, 2012). Menurut Hartika et al. (2014) jumlah leukosit pada ikan berkisar antara 20.000150.000 sel per $\mathrm{mm}^{3}$ darah. Ikan gabus memiliki rata-rata jumlah leukosit di atas kisaran normal. Adebayo et al. (2007) melaporkan jumlah leukosit pada ikan Parachanna obscura dari famili Channidae sekitar $4,01 \times 10^{3} \mathrm{sel} / \mathrm{mm}^{3}$. Jumlah leukosit yang tinggi diduga karena stress pada ikan akibat kualitas air yang buruk dan tercemar. Peningkatan jumlah leukosit disebut leukositosis (Erika, 2008). Jumlah leukosit dipengaruhi oleh beberapa faktor, yaitu spesies ikan, umur, nutrisi dan stress (Modra et al., 1998).

Jumlah leukosit dan eritrosit pada ikan gabus berkorelasi negatif, yaitu semakin tinggi jumlah eritrosit semakin rendah jumlah leukositnya. Menurut Adebayo et al. (2007), jumlah eritrosit dan jumlah leukosit pada ikan $P$. obscura berkorelasi positif. Adanya perbedaan korelasi kemungkinan karena adanya perbedaan umur, nutrisi dan kondisi fisik ikan.

Leukosit dibedakan menjadi dua macam berdasarkan ada dan tidaknya butir-butir (granul) di dalam sel, yaitu granulosit dan agranulosit. Granulosit terdiri atas neutrofil, eosinofil dan basofil sedangkan agranulosit terdiri dari monosit dan limfosit (Campbell \& Ellis, 2013). Hasil dari pengamatan preparat apus darah, diketahui jenis leukosit yang ditemukan adalah monosit, limfosit dan neutrofil. Eosinofil dan basofil tidak ditemukan ketika dilakukan pengamatan. Menurut Jain (1993) eosinofil dan basofil berperan di dalam infeksi parasit dan respon alergi serta dihubungkan dengan penyakit yang bersifat akut. Oleh karena itu, dalam kondisi ikan yang normal atau kondisi kesehatan yang tidak terlalu parah keduanya tidak ditemukan. Ikan gabus jantan memiliki ukuran diameter leukosit yang lebih besar $(7,82 \mu \mathrm{m})$ dibandingkan ikan betina $(7,24 \mu \mathrm{m})$.

Persentase monosit pada ikan gabus betina $(6,53 \%)$ lebih besar dibandingkan pada ikan jantan $(5,73 \%)$. Campbell \& Ellis (2013), melaporkan bahwa jumlah monosit pada ikan Teleostei adalah kurang dari 5\%. Ikan gabus memiliki rata-rata persentase monosit yang tinggi. Hal ini kemungkinan disebabkan adanya infeksi pada ikan. Menurut Robert (2012), jumlah monosit pada ikan akan meningkat dalam waktu yang singkat jika ikan terinfeksi. Monosit pada ikan gabus berukuran besar dengan diameter8-15 $\mu \mathrm{m}$. Bentuk inti selnya bermacam-macam, ada yang berbentuk seperti ginjal hingga yang berbentuk dua lobus besar. Inti sel monosit biasanya mengisi kurang dari 50\% dari volume sitoplasma. Menurut Thrall et al. (2012), monosit pada semua jenis ikan mirip dengan monosit yang ada pada vertebrata lain.

Persentase limfosit pada ikan Teleostei adalah 60$80 \%$ dan persentase neutrofil adalah 6-8\% dari proporsi leukosit yang ada (Robert, 2012). Persentase limfosit pada ikan gabus jantan $(76,13 \%)$ dan betina $(78,20)$ masih berada dalam kisaran normal, sedangkan persentase neutrofil cukup tinggi yaitu pada ikan jantan sekitar 17,40\% dan betina $16,07 \%$. Persentase neutrofil yang tinggi kemungkinan disebabkan adanya stress akibat air yang tercemar. Menurut Modra et al. (1998), persentase neutrofil yang meningkat dapat disebabkan oleh polusi air akibat polutan logam dan organik.

Limfosit ikan gabus berbentuk bulat, memiliki sedikit sitoplasma, tidak bergranula dan berwarna 
biru cerah atau ungu pucat. Bentuk limfosit pada ikan mirip dengan bentuk limfosit pada semua hewan vertebrata (Salasia et al., 2001). Neutrofil pada ikan gabus berbentuk sel bulat yang besar dengan banyak sitoplasma yang jernih dan bergranul. Inti selnya berwarna ungu berbentuk bulat, memanjang dan kadang-kadang membentuk beberapa lobus.

\section{Ucapan Terima Kasih}

Terima kasih kepada Muhammad Martadinata yang telah membantu dalam pengambilan sampel ikan gabus.

\section{Daftar Pustaka}

Adebayo, O.T., O.A. Fagbenro, C.B. Ajayi dan O.M. Popoola, 2007, 'Normal Haematological Profile of Parachanna obscura as a Diagnostic Tool in Aquaculture', International Journal of Zoological Research 3, (4): 193-199, diakses tanggal 30 November 2015

Andayani, S., Marsoedi, Sanoesi, E. Wilujeng, A. E. dan H. Suprastiani. 2014. 'Profil Hematologis Beberapa Spesies Ikan Air Tawar Budidaya',Green Technology. 3: 363-365, diakses tanggal 29 November 2015

Campbell, T.W. \& C.K. Ellis, 2013, Avian and Exotic Animal Hematology, Blackwell Publishing, Iowa

Campbell, T.W., 2015, Exotic Animal Hematology and Cytology, Wiley Blackwell, Iowa

Erika, Y, 2008, Gambaran Diferensiasi Leukosit pada Ikan Mujair (Oreochromis mossambicus) di Daerah Ciampea Bogor, Skripsi, Fakultas Kedokteran Hewan, Institut Pertanian Bogor, Bogor, diakses tanggal 23 September 2016

Hardi, E.H., Sukenda, E. Harris dan A.M. Lusiastuti, 2011, 'Karakteristik dan Patogenitas Streptococcus agalactiae Tipe $\beta$-hemolitik dan Non-hemolitik pada Ikan Nila', Jurnal Veteriner, vol. 12, No. 2:152-164, diakses tanggal 18 Desember 2015

Hartika, R., Mustahal dan A.N. Putra, 2014, 'Gambaran Darah Ikan Nila (Oreochromis niloticus) dengan Penambahan Dosis Prebiotik yang Berbeda dalam Pakan', Jurnal Perikanan dan Kelautan, vol. 4, No. 4: 259-267, diakses tanggal 7 Desember 2015

Hastuti, S. \& Subandiyono, 2011, 'Performa Hematologis Ikan Lele Dumbo (Clarias gariepinus) dan Kualitas Air Media pada Sistim Budidaya dengan Penerapan Kolam Biofiltrasi', Jurnal Saintek Perikanan, vol. 6, No. 2, hal: 1-5, diakses tanggal 11 Januari 2015
Heath, A.G., 1995, Water Pollution and Fish Physiology, CRC Press, Florida

Hidayat, R., E. Harpeni dan Wardiyanto, 2014, Profil Hematologi Kakap Putih (Lates calcallifter) yang Distimulasi dengan Jintan Hitam (Nigela sativa) dan Efektivitasnya terhadap Infeksi Vibrio dengan Alginolyticus, Jurnal Rekayasa dan Teknologi Budidaya Perairan, vol. 3 no. 1, hal: 327-334, diakses tanggal 29 November 2015

Ikeda, T., 1970, Relationship Between Respiration Rate and Body Size in Marine Plankton Animals as a Function of the Temperature of Habitat, Bull. Fac. Fish, XXI 2, diakses tanggal 24 April 2017

Jain, N.C., 1993, Essentials of Veterinary Hematology, Lea \& Febiger, Philadelphia

Klontz, G.W., 2009, Fish Hematology, Ace Learning Company, California

Maciak, S., K. Janko, J. Kotusz, L. Choleva, A. Boron, D. Juchno, R. Kujawa, J. Kozlowski and M. Konarzewski, 2011, 'Standard Metabolic Rate (SMR) is Inversely Related to Erythrocyte and Genome size in Allopolyploid Fish of the Cobitis taenia Hybrid Complex', Functional Ecology 25: 1072-1078, diakses tanggal 15 Januari 2017

Makmur, S. \& D. Prasetyo, 2006, Kebiasaan Makan, tingkat Kematangan Gonad dan Fekunditas Ikan Haruan (Channa striata Bloch) di Suaka Perikanan Sungai Sambujur DAS Barito Kalimantan Selatan, Jurnal Ilmu-ilmu Perairan dan Perikanan Indonesia, Jilid 13, no. 1, hal: $27-$ 31 diakses tanggal 20 April 2017

Modra, H., Z. Svobodova dan J. Kolarova, 1998, Comparison of Differential Leukocyte Counts in Fish of Economic and Indicator Importance, Acta Vet, vol. 67, hal: 215-226 diakses tanggal 7 Desember 2016

Nabib, R. \& F.H. Pasaribu, 1989, Patologi dan Penyakit Ikan, Departemen Pendidikan dan Kebudayaan, Direktorat Jendral Pendidikan Tinggi, Pusat Antar Universitas Bioteknologi, Institut Pertanian Bogor

Onyia, L.U., Michael K.G. dan Ekoto B., 2013, 'Haematological Profile, Blood Group and Genotype of Heterobranchus bidorsalis', Net Journal of Agricultural Science, vol. 1, no.2, hal: 69-72, diakses tanggal 30 November 2015

Pal, G.K. \& P. Pal, 2006, Textbook of Practical Physiology, Orient Longman Private Limited, Hyderabat

Robert, R.J., 2012, Fish Pathology, Wiley-Blackwell, Iowa

Salasia, S.I.O., D. Sulanjari dan A. Ratnawati, 2001, Studi Hematologi Ikan Air Tawar, Biologi 2, (12): 710-723, diakses tanggal 23 Oktober 2016 
Protobiont (2019) Vol. 8 (2) : 1 - 7

Samsisko, R.E.W., 2013, Respon Hematologis Ikan Kerapu Tikus (Cromileptesaltivelis) pada Suhu Media Pemeliharaan yang Berbeda, Skripsi, Fakultas Perikanan dan Kelautan, Universitas Airlangga, Surabaya, diakses tanggal 31 Juli 2016

Santoso, A.G., M. Astawan dan T. Wresdiyanti, 2009, Potensi Ekstrak Ikan Gabus (Channa striata) sebagai Stabilisator Albumin SGOT dan SGPT Tikus yang Diinduksi dengan Parasetamol Dosis Tinggi, Fakutas kedokteran Hewan, Institut Pertanian Bogor, Bogor, diakses tanggal 10 Oktober 2016

Thrall, M.A., G. Weiser, R.W. Allison dan T.W. Campbell, 2012, Veterinary Hematology and Clinical Chemistry, Wiley- Blackwell, Iowa

Vázquez, G.R. \& G.A. Guerrero, 2007, 'Characterization of Blood Cells and Hematological Parameters in Cichlasoma dimerus (Teleostei, Perciformes)', Tissue and Cells, (39): 151-160, diakses tanggal 19 Mei 2016

Weiss, D.J. \& K.J. Wardrop, 2010, Schalm's Veterinary Hematology, wiley-Blackwell, Iowa 